\title{
EVAPORATIVE WATER LOSSES OF SOME SMALL AUSTRALIAN LIZARDS
}

\author{
William R. Dawson, Vaughan H. Shoemaker, ${ }^{1}$ and Paul Licht ${ }^{2}$ \\ Departments of Zoology, The University of Michigan, Ann Arbor, Michigan, and \\ University of Western Australia, Nedlands, Western Australia
}

(Accepted for publication July 1, 1965)

\begin{abstract}
Water losses of small (1.5 to $4.6 \mathrm{~g}$ ) representatives of three species of Austialian lizards, Amphibolurus ornatus (Agamidae), Gehyra variegata (Gekkonidae), and Sphenomorphus labillardicri (Scincidae), were determined from weight losses incurred by the animals in a dry atmosphere. In one set of experiments conducted at $20^{\circ} \mathrm{C}$, the animals were unrestrained in their chambers. The rates of total water loss by $A$. ornatus, $G$. variegata, and $S$. labillardieri aweraged $1.9 \mathrm{~g}$ (100g day $)^{-1}, 3.0 \mathrm{~g}(100 \mathrm{~g} \text { day })^{-1}$, and $6.8 \cdot \mathrm{g}(100 \mathrm{~g} \text { day })^{-1}$, respectively. These rates primarily reflect the evaporative loss of water. The differences among them did not appear to result from differences in activity, for the metabolic rates of $S$. labillardieri and $A$. ornatus both approximated $0.07 \mathrm{cc} \mathrm{O}_{2}(\mathrm{~g} \mathrm{hr})^{-1}$. In a second set of experiments conducted at 20 and $30^{\circ} \mathrm{C}$, the water losses of restrained individuals were compartmentalized. The total loss by $A$. ornatus averaged significantly lower than that by $G$. variegata and $S$. labillardieri at both temperatures. This resulted primarily from differences in pulmonary water loss among the three lizards. At $20^{\circ} \mathrm{C}$ cutaneous loss accounts for $70 \%$ of the evaporative loss by $A$. ornatus and $G$. variegata and $41 \%$ of that by $S$. labillardieri. The percentages are somewhat lower at $30^{\circ} \mathrm{C}$ owing to the greater effect of temperature on pulmonary than on cutaneous loss. The distributions of these three lizards correlate well with these observations on water loss, $A$. ornatus and $G$. varicgata reaching hotter and drier sections of Australia than S. labillardicri.
\end{abstract}

\section{INTRODUCTION}

Lizards occupy an impressive variety of habitats ranging from marine situations to harsh deserts. Comprehensive analyses of their water economies remain to be accomplished, but a substantial beginning has been made within the past few years on measurements of saurian water loss uncler various conditions. Studies of kidney function (Bentley 1959; Khalil and Abdel-Messeih 1959; Shoemaker, Licht, and Dawson 1966), extrarenal excretion of electrolytes (Schmidt-Nielsen and Fänge 1958; Schmidt-Nielsen, Borut, Lee, and Crawford 1963; Templeton 1964; Norris and Dawson 1964), and evaporative water loss (Templeton 1960; Chew and Dammann 1961; Dawson and Templeton 1963; Warburg 1966) have all contributed to this.

Indications that pronounced differences exist among lizards in rates of evaporative water loss (Chew and Dammann 1961; Warburg 1966) and that cutaneous loss of water may be relatively more important in the water economies of these animals than generally supposed (see SchmidtNielsen 1964) make further investigation of these topics highly desirable. Accordingly, we have undertaken to compartmentalize and compare the evaporative water losses of three Australian liz-

1 Present address: Department of Life Sciences and Dry Lands Research Institute, University of California, Riverside, California.

${ }^{2}$ Present address: Department of Zoology, University of California, Berkeley, California. ards: Amphibolurus ornatus (Agamidae), Gehyra variegata ${ }^{3}$ (Gekkonidae), and Sphenomorphus labillardieri (Scincidae). The agamid and the gecko occupy somewhat more xeric situations than the skink, and the three species differ conspicuously in integumentary structure.

\section{Materials and Methods}

The lizards used in this study weighed between 1.5 and $4.6 \mathrm{~g}$, the experimental sample for each species averaging approximately $2.8 \mathrm{~g}$. The geckos and skinks in this size range were adults, whereas the agamids were inmature-adult $A$. ornatus reach approximately $20 \mathrm{~g}$. The restricted weight range was utilized to minimize the influence of variation in size on the results. All animals were collected in the Darling Range in the vicinity of Perth, Western Australia. Except during experiments, they were maintained at $25^{\circ} \mathrm{C}$ with water available ad libitum. Food was not provided during the relatively short period in which they were in captivity. Measurements of water loss by each animal were completed within a week of its capture. These involved determination of weight changes to the nearest $\mathrm{mg}$ as the lizard dehydrated in a dry environment at 20 or $30^{\circ} \mathrm{C}$. All weighings were performed on a Mettler balance of appropriate sensitivity.

${ }^{3}$ Populations currently included in Gehyra variegata appear to comprise two or more species differing in their habitat requirements. Individuals referred to in this study as $G$. variegata were all obtained on granite outcroppings. 
Total rates of zuater loss at $20^{\circ} \mathrm{C}$

Measurements were initially undertaken to compare the rates of total water loss at $20^{\circ} \mathrm{C}$ by lizards of the three species. Cloacal, contents of well-hydrated individuals were removed with a fine capillary tube or blunt probe wrapped in cotton. The animals were placed in individual $500-\mathrm{ml}$ jars which were then sealed. They rested in these jars on wire screen over a layer of Drierite (anhydrous $\mathrm{CaSO}_{4}$ ) that held the humidity at a low level. The animals were briefly removed from their containers several times during the first $24 \mathrm{hr}$ and at 24-hr intervals thereafter. At each of these times, cloacal contents were removed to determine whether or not any fecal material was present, and the animals then weighed. In those rare instances in which such material was found, data for the preceding period were discarded. The periodic removal of the cloacal contents prevented the animals from voiding urine or feces while in the jars. These contents usually consisted of uric acid and varying amounts of fluid; the former representing a negligible percentage of the total weight loss. Thus the changes in weight observed reflect essentially urinary and evaporative water loss. (Since the animals were fasting, their respiratory quotients, i.e., the stoichiometric ratios of carbon dioxide produced to oxygen consumed, probably approximated 0.7 . At this value the weight gained through oxygen consumption would not differ appreciably from that lost through expiration of carbon dioxide.) These experiments were conducted over $96 \mathrm{hr}$ with $A$. ornatus and $G$. variegata and over $70 \mathrm{hr}$ with S. labillardieri.

\section{Metabolic rates at $20^{\circ} \mathrm{C}$}

Results obtained concerning total water loss at $20^{\circ} \mathrm{C}$ indicated different rates of dehydration for the three species. Since these might be associated with differences in metabolic rate, some measurements of oxygen consumption were performed using a simple volumetric respirometer consisting of a 150-ml glass jar, a rubber stopper fitted with an " $L$ "-shaped glass tube, and a 1-ml graduated pipette. The lizard, which had fasted over at least the preceding $24 \mathrm{hr}$, rested in the jar on a wire screen over a layer of Ascarite (a carbon dioxide absorbent) and Drierite. The jar was sealed with the stopper and placed in a water bath at $20^{\circ} \mathrm{C}$, with the horizontal arm of the glass tube just above the surface of the water. The pipette, the bore of which was coated with manometer fluid, was connected to this arm by a short piece of rubber tubing and then secured in a horizontal position. After a 1-hr period for thermal equilibration of the respirometer and adjustment of the lizard to its surroundings, a $2-\mathrm{cm}$ segment of manometer fluid was introduced into the pipette. The inward movement of this segment indicated the oxygen consumption by the animal. Several of these respirometers were used simultaneously, one containing reagents but no animal being used as a thermobarometer. Volumes of oxygen used to specify metabolic rates refer to dry gas at 760 $\mathrm{mm} \mathrm{Hg}$ and $0^{\circ} \mathrm{C}$.

\section{Compartmentalization of rater loss at 20 and $30^{\circ} \mathrm{C}$}

More elaborate steps were required for separation of the water loss by lizards of the three species into its various components. Each animal was fitted with a collar fashioned from a plastic cap for a $15-\mathrm{mm}$ (i. d.) shell vial. An elliptical hole just large enough to admit the head had been cut in the top of this cap. The cap was filled with a 3- or 4-mm layer of a melted paraffin-beeswax mixture. As this cooled to noninjurious temperatures, the hole in the cap was extended through it. The head of the lizard was then passed through this hole and out the top of the cap so the neck was enclosed by the still pliable wax. Finally, this wax was worked with a blunt probe to seal the collar around the animal's neck, without restricting breathing.

The animal with the collar in place was weighed as soon as the contents of the cloaca were removed. Its body was then placed in a shell vial of appropriate size, containing Drierite. This vial was sealed with the cap portion of the collar. Care was taken to ensure that the desiccant in the vial, which served to absorb any water loss through the skin, did not contact the animal. Water lost from the respiratory tract was expired into the external atmosphere. The animal with collar, Drierite, and vial was weighed and then placed with several other sinilarly fitted individuals on a rack in a glass desiccator (10 in. diameter) containing a liberal quantity of Drierite and a small electric fan for circulating air. When this had been done, the desiccator was sealed for a 4- to 12-hr period. At the completion of this period, the animal was removed and weighed with collar, vial, and Drierite, and then with just the collar. Cloacal contents were removed and the animal with its collar reweighed. The vial with fresh Drierite was again sealed with the collar. The assembly was then weighed and returned to the desiccator. This procedure was repeated at 4- to 12 -hr intervals throughout experiments ranging from 20 to $48 \mathrm{hr}$ at $20^{\circ} \mathrm{C}$ and from 14 to 
$60 \mathrm{hr}$ at $30^{\circ} \mathrm{C}$. The lizards rarely voided urine or feces in these periods; instances where they did were readily detected from the presence of feces or uric acid on the wall of the vial. Measurements for these few intervals were discarded. In the remainder, the only appreciable weight changes resulted from removal of material from the cloaca or from evaporative water loss (as noted previously, the weight differential between oxygen consumed and carbon dioxide expired would be negligible).

Pulmonary water loss was taken as the difference between the total weights of animal, collar, vial, and Drierite at the beginning and end of a 4- to 12-hr measurement period. Overall evaporative water loss was taken as the difference between the weights of animal and collar after removal of material from the cloaca at the beginning and before removal of any such material at the end of a measurement period. Cutaneous water loss was determined from the difference between overall evaporative water loss and pulmonary water loss. Urinary water loss was estimated from the loss in weight by the animal and collar upon removal of the cloacal contents at the end of the measurement period, since fecal material was generally absent from the cloaca in these fasted lizards. However, the urine contained uric acid and became reduced in volume and more viscous as dehydration progressed.

The apparent rates of cutaneous and pulmonary water loss determined by these methods probably differ slightly from the true rates. Any water lost through the skin of the head would be reflected as pulmonary water loss; the apparent rates of cutaneous loss are therefore conservative. Values for urinary. water output are only presented to indicate the approximate loss by this route, since the cloacal contents of lizards in the latter stages of dehydration consisted principally of traces of uric acid. Statistical comparison of data for the three species were made using the Mann-Whitney U test (Siegel 1956).

\section{Results}

\section{Total water loss at $20^{\circ} \mathrm{C}$}

The courses of dehydration of Amhibolurus ornatus, Gehyra variegata, and Sphenomorphus labillardieri are indicated by the losses of body weight occurring over the 70 - to $96-\mathrm{hr}$ periods in which these animals were maintained without water in dry air at $20^{\circ} \mathrm{C}$ (Fig. 1). Representatives of each species lost weight most rapidly within the first $6 \mathrm{hr}$ of the experiment. This appeared to result from high levels of activity

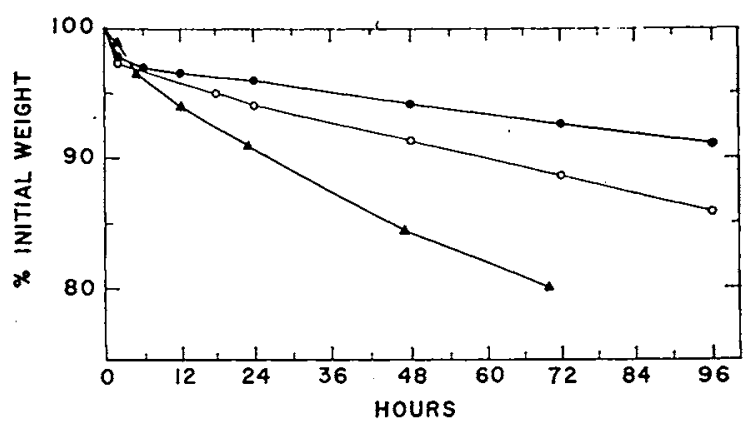

FIG. 1. Mean weights of lizards dehydrating at $20^{\circ} \mathrm{C}$, expressed as percentages of initial weight. Amphibolurus ornatus $(\mathrm{N}=6)$, shaded circles. Gehyra varicgata $(\mathrm{N}=$ 6), unshaded circles. Sphenomorphus labillardicri ( $\mathrm{N}=$ $6)$, triangles. The experimental sample for $S$. labillardieri was reduced to five between 48 and $70 \mathrm{hr}$ with the death of an individual that had lost weight relatively rapidly in the earlier portion of the experiment.

and copious output of urine by relatively well hydrated animals. The rate of weight loss subsequently declined to the level apparent throughout the remainder of the experiment. Beyond the 6 -hour point in the experiments, the rates of weight loss by $A$. ornatus, $G$. variegata, and $S$. labillardieri averaged $1.9 \mathrm{~g}(100 \mathrm{~g} \text { day })^{-1}, 3.0 \mathrm{~g}$ $(100 \mathrm{~g} \text { day })^{-1}$, respectively. Since defecation did not contribute to these rates and urinary water loss was very low, they must primarily reflect evaporative losses of water.

\section{Metabolic rates at $20^{\circ} \mathrm{C}$}

The oxygen consumption of four $A$. ornatus and three $S$. labillardieri, all the animals available at the time, was determined at $20^{\circ} \mathrm{C}$. The rates obtained for the two species both averaged 0.07 $\mathrm{CC}_{2}(\mathrm{~g} \cdot \mathrm{hr})^{-1}$.

\section{Compartmentalization of water loss at 20 and $30^{\circ} \mathrm{C}$}

The major effort in this study concerned separation of the total loss by each species into its evaporative and nonevaporative components, and determination of the pulmonary and cutaneous portions of the former. The results obtained are summarized in Table I. Evaporation is the major cause of water loss in fasting lizards of all three species at both 20 and $30^{\circ} \mathrm{C}$. More than half of this occurs through the skin in $A$. ornatus and $G$. variegata at these temperatures. On the other hand, the major share of the evaporative water loss by $S$. labillardieri at 20 and $30^{\circ} \mathrm{C}$ comes from the respiratory tract.

The skinks appeared less tolerant of a dry atmosphere at $30^{\circ} \mathrm{C}$ than either the agamids or geckos. About half of the $S$. labillardieri failed to survive $12 \mathrm{hr}$ of confinement in collars at this 
TABLE I. Evaporative and approximate urinary water losses in three Australian lizards

\begin{tabular}{|c|c|c|c|c|c|c|c|c|}
\hline \multirow[t]{2}{*}{ Species } & \multirow[t]{2}{*}{$\mathrm{N}$} & \multirow{2}{*}{$\begin{array}{c}\text { Mean total } \\
\text { water loss } \\
\left(\mathrm{ml}[100 \mathrm{~g} \text { day }]^{-1}\right)\end{array}$} & \multicolumn{5}{|c|}{ Evaporative water loss $\left(\mathrm{ml}[100 \mathrm{~g} \text { day }]^{-1}\right)$} & \multirow{2}{*}{$\begin{array}{c}\begin{array}{c}\text { Urinary water } \\
\text { loss } \\
\left(\mathrm{ml}[100 \mathrm{~g} \text { day }]^{-1}\right)\end{array} \\
\text { Mean Range }\end{array}$} \\
\hline & & & $\begin{array}{l}\text { Mean over- } \\
\text { all loss } \\
\quad(a)\end{array}$ & $\begin{array}{l}\text { Pulmonary loss } \\
(b) \\
\text { Mean Range }\end{array}$ & $\begin{array}{l}\text { Cutaneous loss } \\
\text { (c) } \\
\text { Mean Range }\end{array}$ & $\begin{array}{l}b / a \\
(\%)\end{array}$ & $\begin{array}{l}c / a \\
(\%)\end{array}$ & \\
\hline \multicolumn{9}{|c|}{$-20^{\circ} \mathrm{C}-$} \\
\hline $\begin{array}{l}\text { Amphibolorus } \\
\text { ornatus } \\
\text { Gehyra variegata } \\
\text { Sphenomorphus } \\
\text { labillardieri }\end{array}$ & $\begin{array}{r}7 \\
17 \\
7\end{array}$ & $\begin{array}{c}2.98 \\
4.82 \\
7.97\end{array}$ & $\begin{array}{l}2.45 \\
4.43 \\
\\
5.98\end{array}$ & 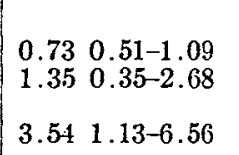 & $\begin{array}{ll}1.72 & 0.52-3.09 \\
3.08 & 1.24-6.89 \\
& \\
2.44 & 1.25-3.99\end{array}$ & $\begin{array}{l}30 \\
30 \\
59\end{array}$ & $\begin{array}{l}70 \\
70 \\
41\end{array}$ & $\begin{array}{rr}0.53 & 0.07-1.86 \\
0.39 & 0.12-0.81 \\
1.99 & 1.13-10.50\end{array}$ \\
\hline \multicolumn{9}{|c|}{$-30^{\circ} \mathrm{C}-$} \\
\hline $\begin{array}{l}\text { A. ornatus } \\
\text { G. variegata } \\
\text { S. labillardieri }\end{array}$ & $\begin{array}{l}6 \\
7 \\
5\end{array}$ & $\begin{array}{r}3.52 \\
6.59 \\
15.97\end{array}$ & $\begin{array}{r}2.91 \\
6.34 \\
15.71\end{array}$ & 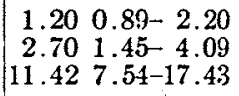 & $\begin{array}{ll}1.71 & 0.51-3.13 \\
3.64 & 2.48-5.72 \\
4.29 & 3.34-5.30\end{array}$ & $\begin{array}{l}41 \\
43 \\
73\end{array}$ & $\begin{array}{l}59 \\
57 \\
27\end{array}$ & $\begin{array}{lr}0.61 & 0.15-1.30 \\
0.25 & 0.06-0.83 \\
0.26 & 0-0.76\end{array}$ \\
\hline
\end{tabular}

temperature. All of the $A$. ornatus and G. varicgata survived such confinement for at least 24 $\mathrm{hr}$, and the majority survived for much longer periocls. The $30^{\circ} \mathrm{C}$ level appears well below that required to produce heat injury in any of these lizards (Licht, Daw'son, and Shoemaker 1966). Perhaps the deaths that did occur, particularly in $S$. labillardicri, resulted from excessive dehydration at this temperature. Unfortunately, it was impractical to determine the extent of dehydration of the lizards at death. Whatever the cause of the difficulty, care was taken to reject any data for individuals that appeared distressed or injured at $30^{\circ} \mathrm{C}$.

Total water output at $30^{\circ} \mathrm{C}$ was greater than at $20^{\circ} \mathrm{C}$ in all three lizards, $Q_{10}$ for the increase approximating 1.2 in $A$. ornatus, 1.5 in G. variegata, and 2.6 in $S$. labillardieri. The individual components of the water loss were affected to different extents by the rise in temperature. Pulmonary water loss underwent the largest relative increase, $Q_{10}$ for this function approximating 1.6, 2.0, and 3.2 in the agamid, gecko, and skink, respectively. Cutaneous water loss appeared unaffected by temperature in $A$. ornatus and had $Q_{10}$ 's of 1.2 and 1.8 in $G$. variegata and $S$. labillardieri, respectively.

Urinary water loss did not increase appreciably between 20 and $30^{\circ} \mathrm{C}$ in any of the three species, and actually decreased in $S$. labillardieri. These results are not surprising, for the rate of urine output in these lizards appears directly correlated with their level of hydration, this rate declining as their water deficit increases. The more rapid dehydration occurring at $30^{\circ} \mathrm{C}$ must have produced an early curtailment of urine production.

\section{Discussion}

Interspecific variation in water loss

Indications of interspecific variation in rates of saurian water loss have been noted in the family Iguanidae by Chew and Dammann (1961) and by Dawson and Templeton (1963). More recently, Warburg (1966) has reported considerable variation in such rates among a large number of Australian agamids, geckos, and skinks. Assessment of the full extent of the differences noted and interpretation of their adaptive significance, if any, has been hindered to some extent by differences in techniques and body temperature between studies and by differences in weight between species. The application of standardized procedures to animals of similar size in the present study has circumvented these difficulties.

As noted previously, the mean rates of total weight loss at $20^{\circ} \mathrm{C}$ in the dehydration experiments summarized in Figure 1 differed among $A$. ornatus, $G$, variegata, and $S$. labillardieri. The rates-for the agamid and gecko are considerably lower than that for the skink, and representatives of $S$. labillardieri had lost weight significantly $(P<0.01)$ more rapidly than nembers of either of the other two species. The mean rate of total weight loss by dehydrating $A$. ornatus is also significantly lower than that by $G$. variegata $(P<0.02)$. 
TABLE II. Comparison of evaporative and urinary water losses of three species of Australian lizards ${ }^{\mathbf{a}}$

\begin{tabular}{|c|c|c|c|c|c|}
\hline \multirow[b]{2}{*}{ Comparison } & \multirow{2}{*}{$\begin{array}{l}\text { Temperature } \\
\left({ }^{\circ} \mathrm{C}\right)\end{array}$} & \multirow{2}{*}{$\begin{array}{c}\text { Total water } \\
\text { loss }\end{array}$} & \multicolumn{2}{|c|}{ Evaporative water loss } & \multirow{2}{*}{$\begin{array}{l}\text { Urinary } \\
\text { water lose }\end{array}$} \\
\hline & & & Pulmonary & Cutaneous & \\
\hline $\begin{array}{l}\text { Amphibolurus ornatus vs } \\
\text { Gehyra variegata }\end{array}$ & $\begin{array}{l}20 \\
30\end{array}$ & $\begin{array}{l}\text { A. }<G . \quad(P<0.05) \\
\text { A. }<G . \quad(P<0.01)\end{array}$ & $A .<G . \stackrel{\text { n.s. }}{(P<0.01)}$ & $\begin{array}{l}\text { A. }<G . \quad(P=0.05) \\
A .<G . \quad(P<0.01)\end{array}$ & $\begin{array}{l}\text { n.s. } \\
\text { n.s. }\end{array}$ \\
\hline $\begin{array}{l}\text { Amphibolurus ornatus } \\
\text { vs Sphenomorphus labillardieri }\end{array}$ & $\begin{array}{l}20 \\
30\end{array}$ & $\begin{array}{l}\text { A. }<S . \quad(P<0.01) \\
\text { A. }<S . \quad(P<0.01)\end{array}$ & $\begin{array}{l}A .<S . \quad(P<0.01) \\
A .<S .(P<0.01)\end{array}$ & A. $<S . \stackrel{\text { n.s. }}{(P<0.01)}$ & $\begin{array}{l}\text { n.s. } \\
\text { n.s. }\end{array}$ \\
\hline $\begin{array}{l}\text { Gehyra variegata } \\
\text { vs Sphenomorphus labillardieri }\end{array}$ & $\begin{array}{l}20 \\
30\end{array}$ & $\begin{array}{ll}G .<S . & (P=0.05) \\
G .<S . & (P<0.01)\end{array}$ & $\begin{array}{ll}G .<S . & (P<0.01) \\
G .<S . & (P<0.01)\end{array}$ & $\begin{array}{l}\text { n.s. } \\
\text { n.s. }\end{array}$ & $\begin{array}{l}\text { n.s. } \\
\text { n.s. }\end{array}$ \\
\hline
\end{tabular}

sDouble-tailed probabilities. The following abbreviations are used: A. (Amphibolurus ornatus); G. (Gehyra tariejata); S. (Sphenomorphus labillardieri); n.s. (not significant at $5 \%$ level).

The experiments in which water losses at 20 and $30^{\circ} \mathrm{C}$ were compartmentalized allow a more detailed consideration of the differences among the three species (Tables I and II). A. ornatus has significantly lower mean rates of total water loss at these temperatures than $G$. variegata and $S$. labillardieri. The rates for the gecko were also significantly lower than those for the skink. These results are consistent with those summarized in Fig. 1. A. ornatus also has significantly lower rates of pulmonary water loss than S. labillardieri at 20 and $30^{\circ} \mathrm{C}$ and $G$. variegata at $30^{\circ} \mathrm{C}$. Losses by this route are significantly lower in the gecko than in the skink at these temperatures. Since these animals were all exposed to similar environmental conditions, these observations on pulmonary water loss imply differences in the rates at which their respiratory tracts are ventilated. Such differences could result from differences in the extent to which these lizards adjusted to the restraint imposed upon them by the use of the collars-S. labillardicri might struggle and therefore ventilate more than the other two species, and $G$. variegata might do likewise in comparison with $A$. ornatus. However, comparison of the rates of total water (or weight) loss for unrestrained (Fig. 1) and restrained (Table I) individuals of the three species at $20^{\circ} \mathrm{C}$ does not appear to support this possibility. The rates for the latter individuals were 1.6 times those for unrestrained ones in both $A$. ornatus and $G$. variegata. On the other hand, representatives of $S$. labillardieri fitted with collars lost water at only about 1.2 times the rate for unrestrained individuals of these species.

If differences in response to restraint are ruled out, only two explanations of the differences in rates of pulmonary water loss among the three species appear possible. Perhaps the skink is inherently more active at $20^{\circ} \mathrm{C}$ than the agamid or gecko, and the gecko more so than the agamid. The similarity of the rates of oxygen consumption by $S$. labillardieri and $A$. ornatus suggest that this is not the case. The other possibility is that differencés might exist among the three species in the amount of ventilation required to effect the consumption of a given volume of oxygen. Evaluation of this must await simultaneous measurement of pulmonary water loss, ventilation, and oxygen consumption by these lizards.

The situation concerning the cutaneous water losses of the three lizards is rather complicated (Tables I and II). A. ornatus loses significantly less water by this route than $G$. zariegata at 20 and $30^{\circ} \mathrm{C}$ and $S$. labillardieri at $30^{\circ} \mathrm{C}$. The rates for the agamid and the skink do not differ significantly at $20^{\circ} \mathrm{C}$. The cutaneous water losses by $G$. variegata and $S$. labillardieri do not differ significantly at either temperature. The basis of the differences that do exist among the three species is obscure. It would be of interest to determine the extent of their relation to the pronounced differences in the body form and integumentary structure of these lizards.

The absence of a temperature effect upon cutaneous water loss of $A$. ornatus and the small extent of this effect in $G$. variegata are striking in view of the increase in the capacity of air to carry water vapor between 20 and $30^{\circ} \mathrm{C}$. The saturation pressure for water vapor increases about 1.8 times over this range, from approximately $18 \mathrm{~mm} \mathrm{Hg}$ to $32 \mathrm{~mm} \mathrm{Hg}$. Since the air surrounding the animals' bodies was quite dry owing to the presence of Drierite in the vials, the saturation deficit must have increased appreciably from 20 to $30^{\circ} \mathrm{C}$. Evidently, cutaneous loss of water in these two species of lizards is mainly limited over a considerable range of saturation deficits by the rate at which water can diffuse through the skin. 


\section{Cutaneous versus pulmonary water loss}

Reptilian skin has long been regarded as having a low permeability to water (see Chew 1961). Rates of cutaneous loss are indeed low, particularly in comparison with those of amphibians (Hall and Root 1930). Under in vitro conditions, evaporative loss through the skin of Lacerta viridis and Uromastix acanthinurus proceeds at less than a tenth the rate for Rana temporaria (Tercafs 1963). However, such loss can represent a significant proportion of the water output by reptiles, particularly at moderate temperatures. Chew and Dammann (1961) estimated that a third of the total evaporative water loss by the rattlesnake Crotalus atrox occurred through the skin at 26 to $27^{\circ} \mathrm{C}$. Cutaneous losses account for $70 \%$ of the evaporative water loss at $20^{\circ} \mathrm{C}$ in $A$. ornatus and $G$. variegata and $41 \%$ in $S$. labillardieri. The lower percentage in the skink reflects the high rate of pulmonary water loss by this animal at $20^{\circ} \mathrm{C}$. Cutaneous losses represent 59,57 , and $27 \%$ of the total evaporative water loss at $30^{\circ} \mathrm{C}$ by $A$. ornatus, $G$. variegata, and $S$. labillardieri, respectively. These percentages are less than the corresponding ones for $20^{\circ} \mathrm{C}$ because of the greater effect of temperature on pulmonary than on cutaneous loss. It will be of interest to compare these results with those for other species of lizards differing from the ones treated in this study in size, body form, integumentary structure, and ecology.

\section{Ecological considerations}

The distributions of the lizards dealt with in this study appear to correlate well with the information obtained on their water losses. $A$. ornatus and $G$. variegata tend to reach the hotter and drier parts of Western Australia, whereas $S$. labillardieri is mainly found in the cooler and moister areas. The gecko is nocturnal and should therefore encounter lower temperatures and smaller saturation deficits while abroad than the diurnal $A$. ornatus. This gecko also appears to curtail its activity during the hot and dry summer months, remaining in protected situations. The finding that the agamid loses water more slowly than the gecko or the skink agrees with Warburg's (1966) conclusion that where differences in water loss exist among Australian lizards of these families, the agamids have the lowest rates.
ACKNOWLEDGMENTS

We are grateful to $\mathrm{H}$. Waring for making available to us space and facilities of the Department of Zoology, the University of Western Australia. A. R. Main of that department facilitated our work in many ways, and his aid even extended to collecting skinks while avoiding dugites (Demansia nuchalis) in a drenching rain. Our work was supported in part by grants to W. R. Dawson from the National Science Foundation (G-23137), the Guggenheim Foundation, and the Horace H. Rackham School of Graduate Studies, The University of Michigan. It was carried out while $\dot{V}$. H. Shoemaker and P. Licht held Cooperative Graduate Fellowships from the National Science Foundation.

\section{Literature Cited}

Bentley, P. J. 1959. Studies on the water and electrolyte metabolism of the lizard Trachysaurus rugosus (Gray). J. Physiol. 145: 37-47.

Chew, R. M. 1961. Water metabolism of desertinhabiting vertebrates. Biol. Rev. 36: 1-31.

, and A. E. Dammann. 1961. Evaporative water los' of small vertebrates, as measured with an infrared analyzer. Science 133: 384-385.

Dawson, W. R., and J. R. Templeton. 1963. Physiological responses to temperature in the lizard Crotaphytus collaris. Physiol. Zoöl. 36: 219-236.

Hall, F. G., and R. W. Root. 1930. The influence of humidity on the body temperature of certain poikilotherms. Biol. Bull. 58: 52-58.

Khalil, F., and G. Abdel-Messeih. 1959. The storage of extra water by various tissues of Varanus griseus Daud. Z. vergl. Physiol. 42: 415-421.

Licht, P., W. R. Dawson, and V. H. Shoemaker. 1966. Heat resistance of some Australian lizards. Copeia (in press).

Norris, K. S., and W. R. Dawson. 1964. Observations on the water economy and electrolyte excretion of chuckwallas (Lacertilia, Sauromalus). Copeia $1964: 638-646$.

Schmidt-Nielsen, K. 1964. Desert animals. Oxford Univ. Press.

A. Borut, P. Lee, and E. Crawford, Jr. 1963. Nasal salt secretion and the possible function of the cloaca in water conservation. Science 142: 1300 1301 .

- and R. Fänge. 1958. Salt glands in marine reptiles. Nature 182: 783-785.

Shoemaker, V. H., P. Licht, and W. R. Dawson. 1966. Effects of temperature on kidney function in the lizard Tiliqua rugosa. Physiol. Zoöl. (in press).

Siegel, S. 1956. Nonparametric statistics. McGrawHill Book Co., New York.

Templeton, J. R. 1960. Respiration and water loss at the higher temperatures in the desert iguana, Dipsosaurus dorsalis. Physiol. Zoöl. 33: 136-145.

- 1964. Nasal salt excretion in terrestrial lizards. Comp. Biochem. Physiol. 11: 223-229.

Tercafs, R. R. 1963. Phénomènes de perméabilité au niveau de la peau des reptiles. Arch. Intern. Physiol. Biochem. 71: 318-320.

Warburg, M. R. 1966. On the water economy of several Australian geckos, agamids, and skinks. Copeia (in press). 